\title{
The Mannapra syenite, Central Kerala, India: Geochemistry, petrogenesis and bearing on anorogenic magmatism
}

\author{
$M$ SANTOSH and $\mathrm{K} G$ THARA \\ Centre for Earth Science Studies, P.B. 2235, Sasthamangalam, Trivandrum 695010, India.
}

MS received 27 January 1984; revised 15 September 1984

\begin{abstract}
Occurrence of a syenite body near Mannapra, Trichur district, Kerala, is reported. The syenite, emplaced within charnockitic country rocks along the Idamalayar faultlineament, is exposed over an area of $8 \mathrm{~km}^{2}$. The rock, classified as quartz alkali feldspar syenite based on Q-A-P proportions, has alkali feldspar as the dominant mineral constituent which shows variation in perthitic texture from crypto- to micro- and patch-perthites. Both ortho- and clino-pyroxenes are present, with the former showing blebs of plagioclase suggesting Al-unmixing. Clinopyroxene shows subsolidus reequilibration with greenish pleochroic grain margins and local conversion to alkali amphibole. The petrochemical characters indicate that the syenite crystallized from a partial melt which equilibrated from $\mathrm{K}$ rich, $\mathbf{R b}$-depleted source in the upper mantle, in response to crustal distension and mantle degassing prior to the rifting of the continent. Reaction between early formed minerals and the late peralkaline liquid towards the residual phase resulted in subsolidus reequilibration textures. The syenite is envisaged to be yet another example of the manifestation of anorogenic magmatism in this part of the Indian shield.
\end{abstract}

Keywords. Syenite; mineralogy; geochemistry; petrogenesis; subsolidus reequilibration; anorogenic magmatism.

\section{Introduction}

Occurrences of a number of alkali plutons have been recently noted in the Kerala region, showing spatial relationship with regional fault-lineaments (e.g. Nair et al 1983; Santosh and Nair 1985). As the region occupies a significant portion of the southwestern part of the Indian shield and the western continental margin of India, studies on the petrochemistry and tectonics of these intrusives have been taken up to understand their role in the geologic and tectonic evolution of the region. Available geochronologic data suggest a Late Precambrian-Early Paleozoic taphrogenic magmatism with imprints of related metallogeny to which phase the alkaline intrusives and pegmatites of the region are correlated (Santosh and Nair 1983; Santosh 1984a).

The close relationship between alkaline magmatism and rift-tectonics is well known (Bailey 1974; Murthy and Venkataraman 1964). As the plutons, ranging from alkali granites to alkali syenites and carbonatites (Nair et al 1984a, b) are spatially related to fault-lineaments which have probable mantle extension, it is presumed that the magmatism which is anorogenic in nature, is a precursor to the rift-tectonics of the continental margin (Santosh and Nair 1985). The occurrence of a syenite pluton near Mannapra, Trichur district, Kerala, is reported here. Based on its geochemical characters, an attempt has been made to evaluate its petrogenetic aspects.

\section{Geological setting}

The major part of the lithology of the Trichur district comprises charnockite group of rocks made up of hypersthene and/or diopside bearing granulites and hornblende 


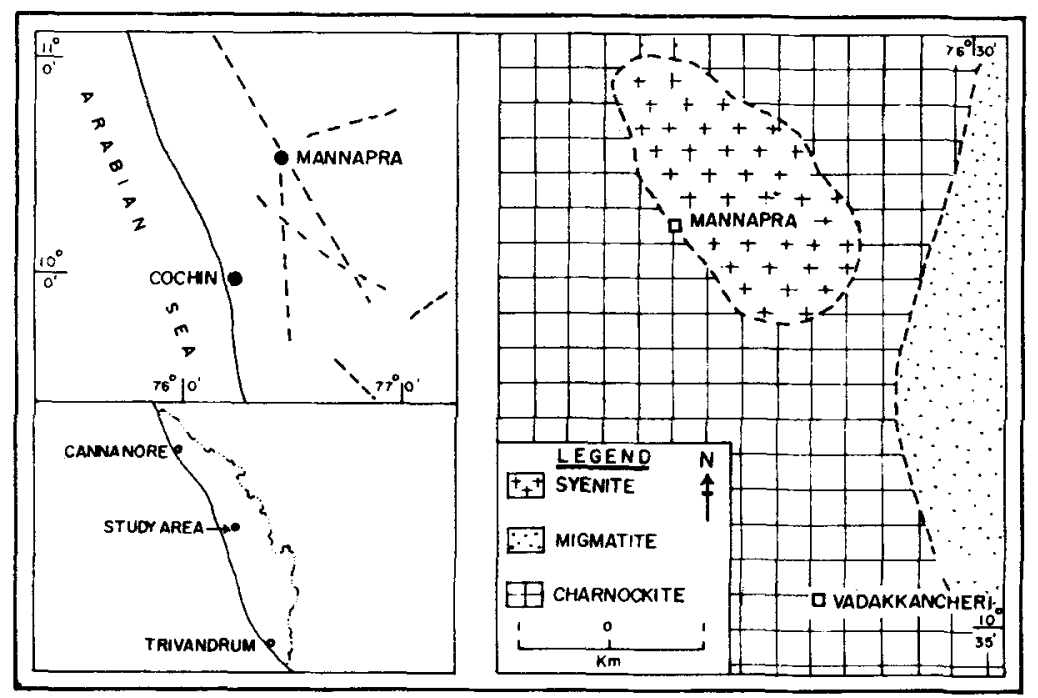

Figure 1. Generalised geological map of the Mannapra area. The inset shows location of the syenite along the NW-SE trending Idamalayar fault-lineament.

granulites (Mahadevan 1964; Rao 1978). The charnockites show development of a foliation which has a general NNW-SSE to N-S trend with steep dips towards west. In the Mannapra locality, the charnockite is medium to coarse-grained variety with a feeble NW-SE foliation trend. Towards east of the locality, the charnockites show contact with migmatitic gneisses containing hornblende and biotite.

The syenite is exposed as a NW-SE elongated body around $8 \mathrm{~km}^{2}$ within the charnockites near the charnockite-migmatite contact. It occurs along the NW-SE trending Idamalayar lineament (figure 1). This lineament is an active fault along which a suite of gabbroic dykes of Tertiary age and the alkaline pluton of Sholayar are emplaced (Tilak 1980; Nair et al 1984b; Santosh and Sankar 1984). The syenite shows rather sharp contacts with the charnockitic rocks. From the quartz-hypersthenefeldspar assemblage of the charnockite, there is an abrupt change to interlocking pyroxene-feldspar assemblage of the syenite as discernible in few localities. The syenite is medium-to-coarse grained at its exposed peripheries and tends to be coarse grained towards the centre.

\section{Mineralogy}

In thin sections, the syenite shows a general hypidiomorphic granular texture. However, the alkali feldspar tends to form megacrysts in some cases. The mineralogical assemblage comprises alkali feldspar, orthopyroxene, clinopyroxene and amphibole with minor plagioclase, biotite and opaques. Accessories include apatite, zircon, sphene, epidote, chlorite and calcite. Point counting with an electrical integrator shows average model contents of $4.2 \%$ quartz, $72.1 \%$ alkali feldspar, $5.5 \%$ plagioclase, $7.2 \%$ pyroxenes, $3.3 \%$ amphibole, $2.4 \%$ biotite and $2.2 \%$ opaques with accessories

Figure 2. Photomicrographs (in crossed nicols, except d) of Mannapra syenite. The length of photographs $\mathrm{a}, \mathrm{b}$ and $\mathrm{d}$ is $6 \mathrm{~mm}$ and $\mathrm{c}$ is $3 \mathrm{~mm}$. (a)-Perthitic $\mathrm{K}$-feldspar. (b)-Orthopyroxene showing blebs of exsolved plagioclase. (c)-Plagioclase lath showing lamellar twinning in orthopyroxene. (d)-Biotite flakes fringing magnetite grain. 
a

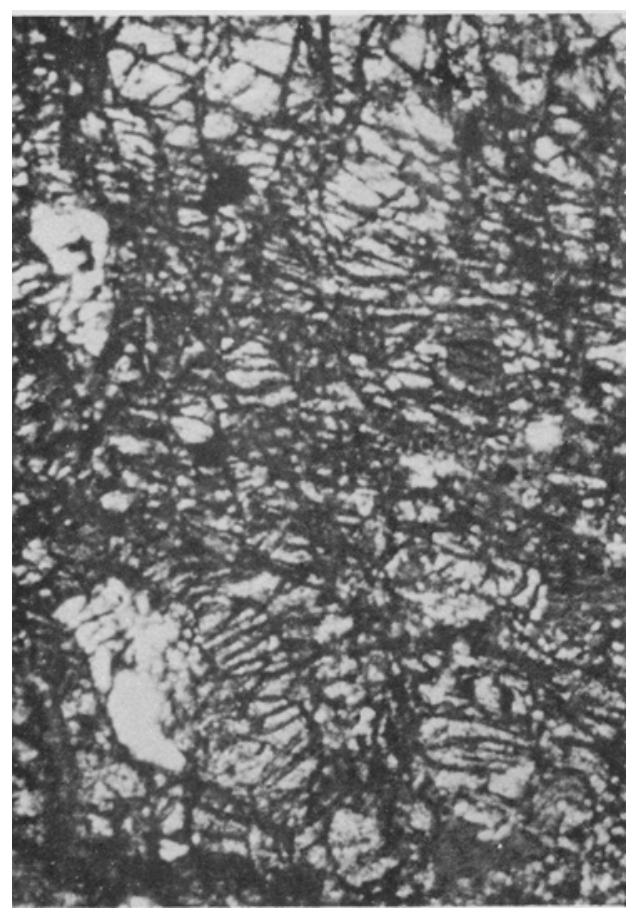

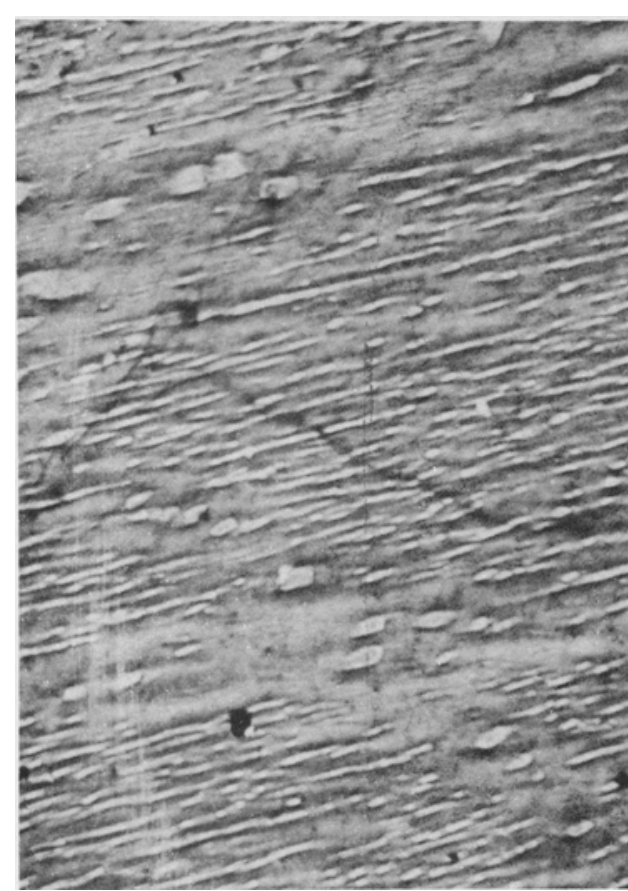

网
ธิ
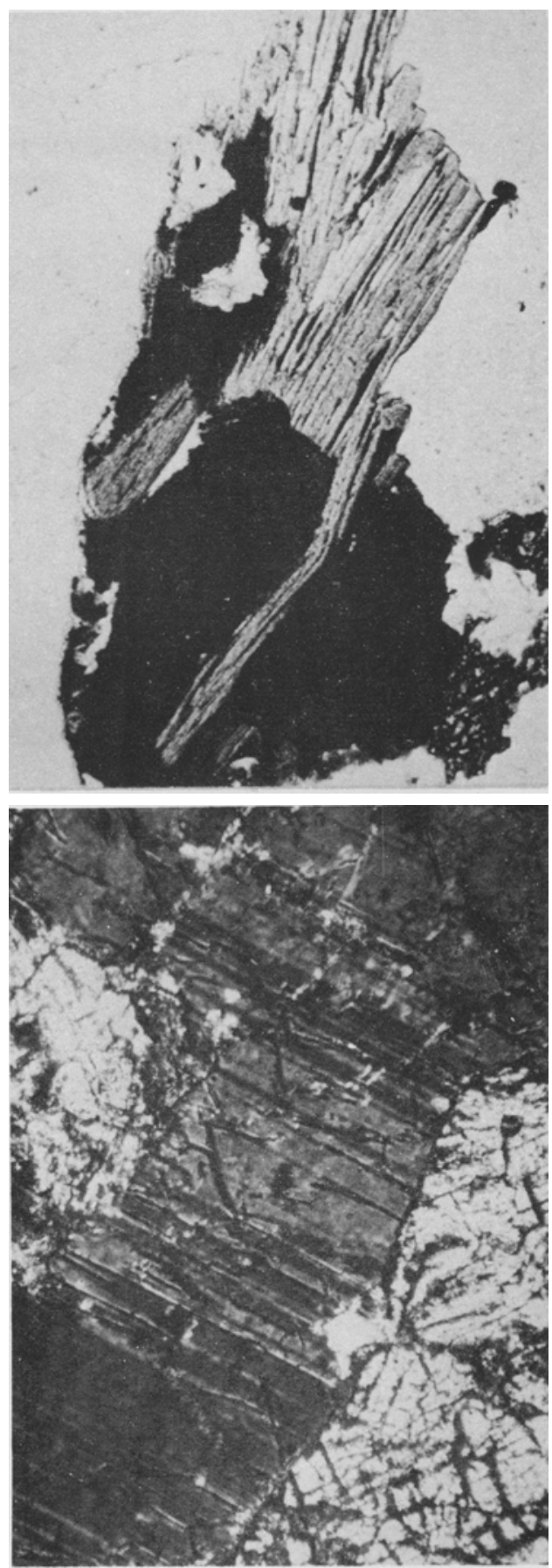

은 


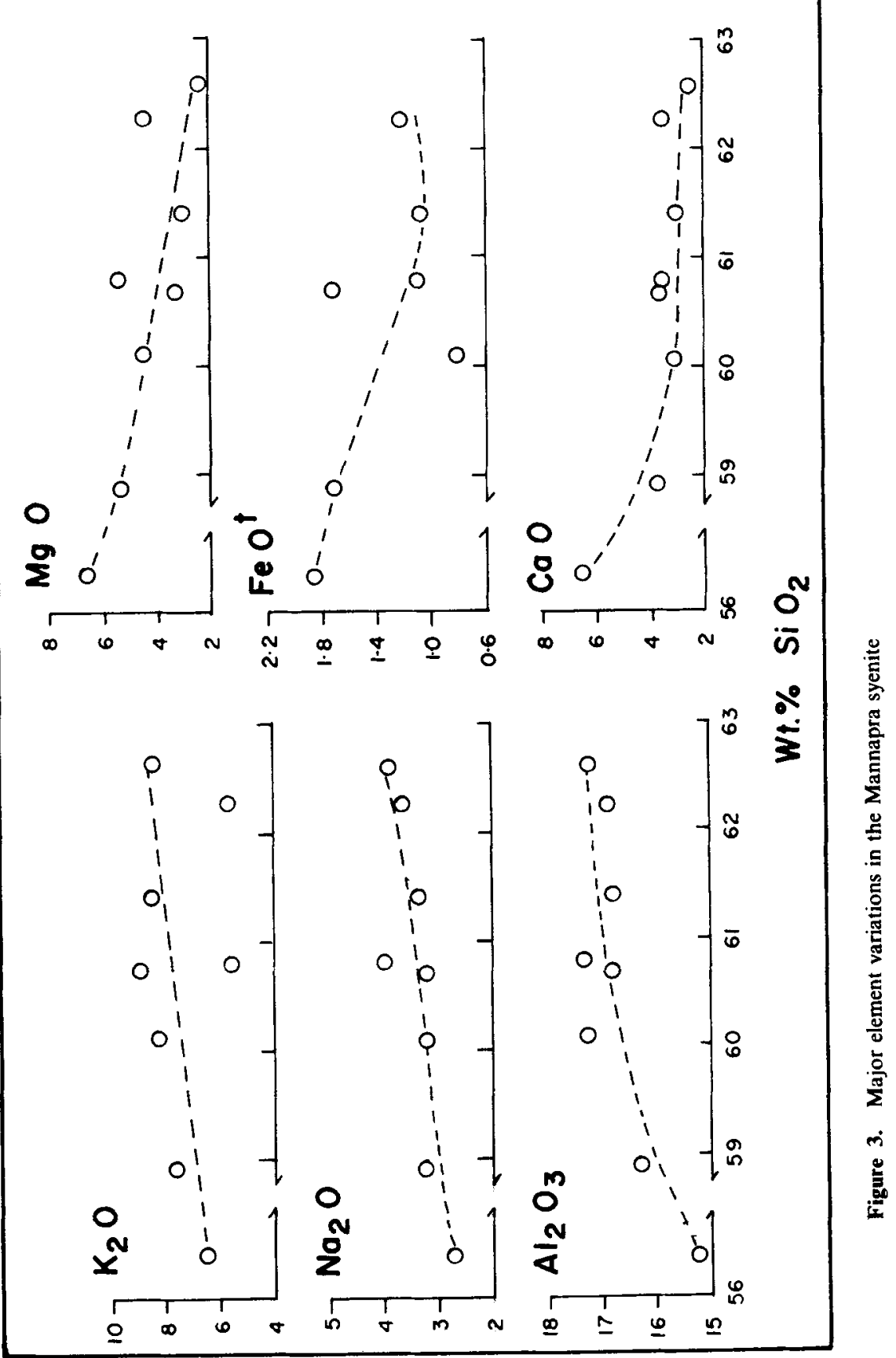



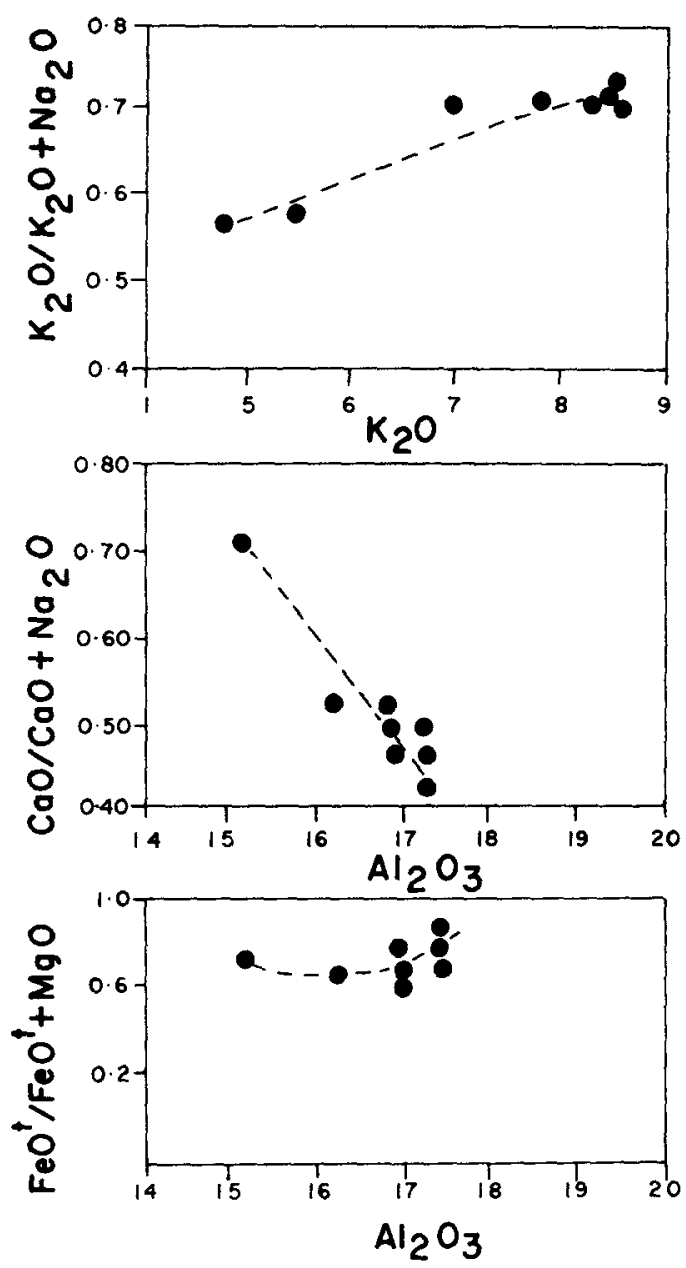

Figure 4. $\mathrm{K}_{2} \mathrm{O} / \mathrm{K}_{2} \mathrm{O}+\mathrm{Na}_{2} \mathrm{O}$ is $\mathrm{K}_{2} \mathrm{O}, \mathrm{CaO} / \mathrm{CaO}+\mathrm{Na}_{2} \mathrm{O}$ is $\mathrm{Al}_{2} \mathrm{O}_{3}$ and $\mathrm{FeO}^{t} / \mathrm{FeO}^{t}+\mathrm{MgO}$ is $\mathrm{Al}_{2} \mathrm{O}_{3}$ diagrams.

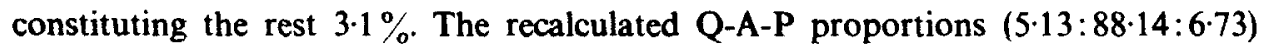
correspond to that of quartz alkali feldspar syenite, following Streckeisen's (1976) scheme.

Alkali feldspar, which forms the dominant mineral constituent, occurs as subhedral to anhedral grains exhibiting varied perthitic textures. The exsolved Na-phase in the host $\mathbf{K}$-feldspar that generally lacks microcline cross-hatching is found as braids to coarser blebs and patches. The perthitic textures could be classified as varying from fine cryptoperthite to coarse braid microperthite and patch perthite (figure 2a). Plagioclase is relatively rare and occurs as subhedral laths showing lamellar twinning with extinction angles corresponding to $a$ range in composition of $A b_{90} A n_{10}$ to $A b_{80} A n_{20}$. Plagioclase is generally seen as minor discrete grains but also occurs as inclusions in alkali feldspar.

Pyroxene constitute the major mafic silicate in the syenite and occur as large subhedral crystals. In the absence of data on mineral chemistry, estimation of their 


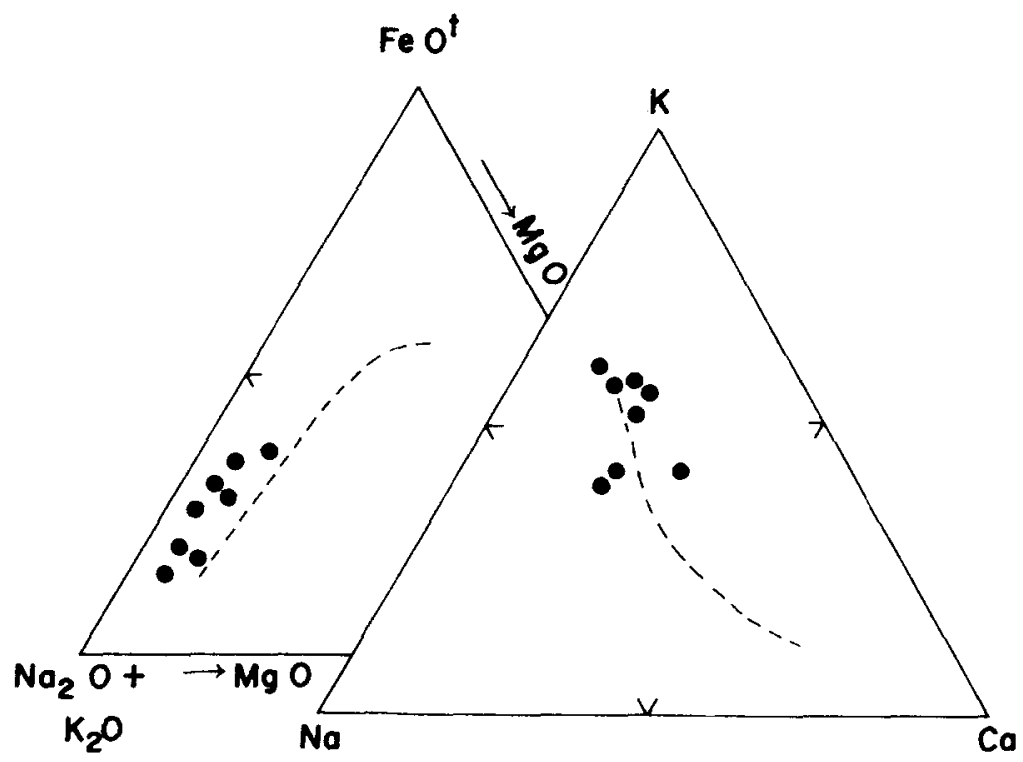

Figure 5. A-F-M and K-Na-Ca variations in the syenite. The broken line represents calcalkaline trend (after Barker and Arth 1976).

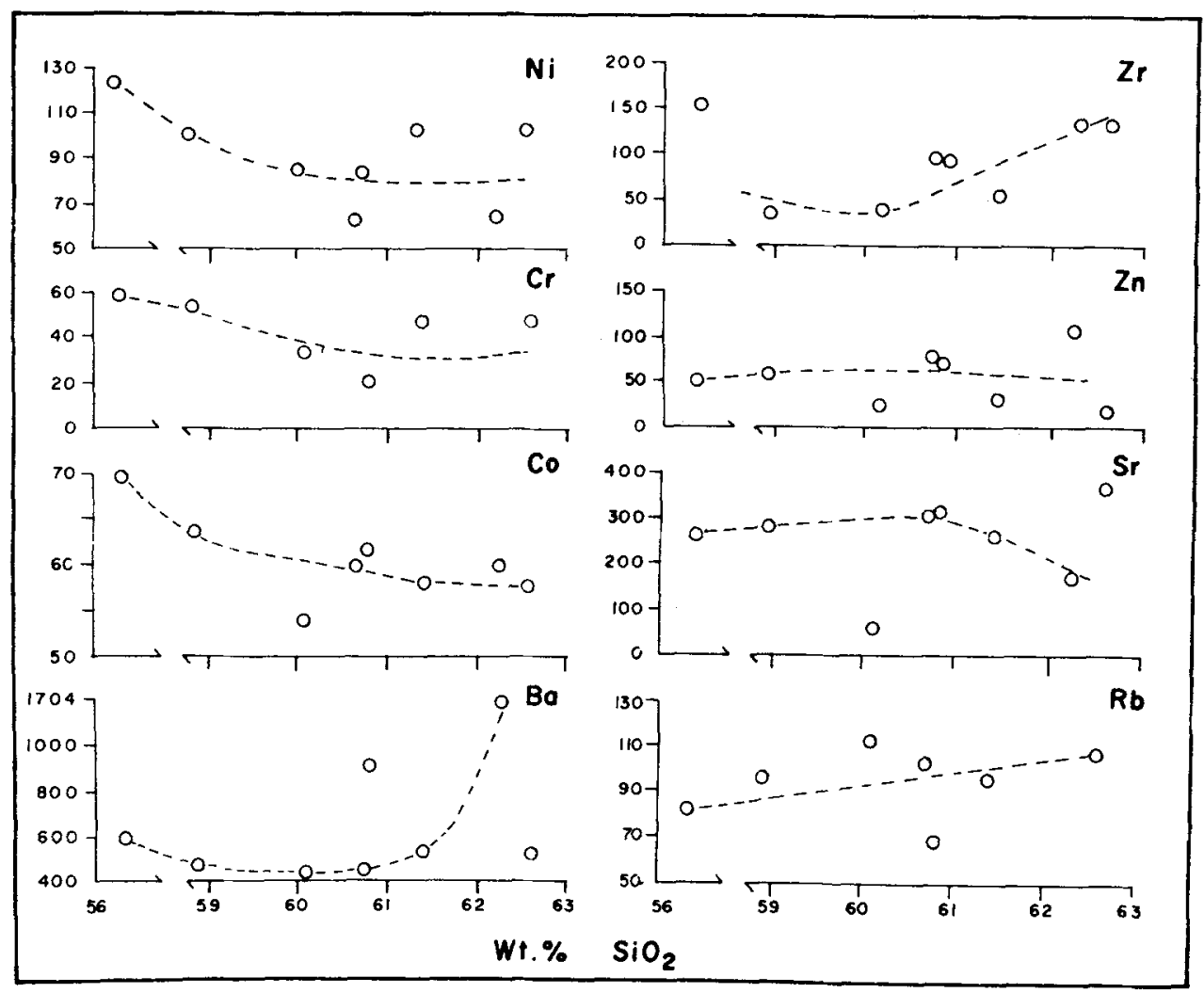

Figure 6. Trace element variations in the Mannapra syenite. 
precise composition is difficult. But some inferences could be drawn based on their optical characters. Both ortho- and clino-pyroxenes are present in the syenite, with the latter being more dominant. The orthopyroxene shows moderate pleochroism with an absorption as $X=$ pale pink, $Y=$ yellowish green and $Z=$ greenish pink. Basal sections of the orthopyroxene show symmetrical extinction and (001) sections show straight extinction. Elongated patches of plagioclase are observed within the orthopyroxene laths (figures $2 b, c)$. This texture closely resembles that described by Emslie (1975) and suggests Al-unmixing from the pyroxene solid solution as a result of lowering of pressure. Clinopyroxene is pale brownish and non-pleochroic with $\mathrm{Z} \Lambda \mathrm{c}$ $=40-44^{\circ}$. In many cases, the grain margins show feeble to moderate pleochroism with $X=$ greenish brown, $Y=$ greenish yellow and $Z=$ green with a slight increase in the $\mathrm{Z} \Lambda \mathrm{c}$ value. The pyroxenes are rarely fresh and unaltered. A moderate degree of subsolidus alterations is common, characterised by the development of greenish amphiboles. Some grains show partial breakdown to an assemblage of magnetitebiotite turquoise chlorite-amphibole.

In addition to the occurrence as a subsolidus reaction product, amphibole is also found as discrete laths exhibiting strong pleochroism as $\mathrm{X}=$ greenish yellow, $\mathrm{Y}$ $=$ yellowish green and $Z=$ deep green with $Z \Lambda c=13^{\circ}$, indicative of an alkaline composition.

Biotite is found as two textural varieties. It generally occurs as thin laths fringing magnetite grains (figure $2 \mathrm{~d}$ ). Biotite is also found as an interstitial phase along with amphibole and quartz. In both cases, it shows moderate pleochroism from brownish yellow to reddish brown. Euhedral crystals of zircon and apatite are generally found as inclusions within pyroxenes. Calcite is apparently primary as it is not found as an alteration product along with other ferromagnesium minerals, but frequently occurs as in interstitial phase between the grain boundaries of alkali feldspars, comparable with similar occurrences in other alkaline rocks of the region (Nair and Santosh 1984a). The opaques are mainly represented by magnetite and subordinate ilmenite. Minor pyrite and chalcopyrite are also found.

\section{Geochemistry}

Eight representative samples of the Mannapra syenite were analysed for major and selected trace elements. The samples for analyses were collected from working quarries around Mannapra area. Major elements were analysed by wet chemical methods and trace elements by atomic absorption spectrophotometer (Perkin-Elmer 4000). The precision and accuracy were checked by performing duplicate analyses. The analytical data summarised in table 1, shows comparison with average values of the Sholayar syenite (SH), an alkali feldspar syenite in central Kerala (Nair et al 1984b) and with those averaged for alkali syenite (AS) by Nockolds (1954). All the analyses show quartznormative character with significant amount of normative diopside implying alkaline nature (table 2).

The $\mathrm{SiO}_{2}$ content shows a moderate variation from 58.94 to 62.62 with a mean at 60-45, comparable with $\mathrm{AS}(61 \cdot 86)$ and $\mathrm{SH}(64 \cdot 14) . \mathrm{Al}_{2} \mathrm{O}_{3}$ values are fairly consistent with a mean at 16.76. The variations in the levels of $\mathrm{Fe}_{2} \mathrm{O}_{3}(1.53-5 \cdot 21), \mathrm{FeO}(1.02-2 \cdot 79)$, $\mathrm{CaO}(2.46-6.94)$ and $\mathrm{MgO}(0.80-1.76)$ are significant and show mean values $(2.81,1.88$, 3.86 and 1.34 respectively) which are comparable with those of SH and AS, except in the 


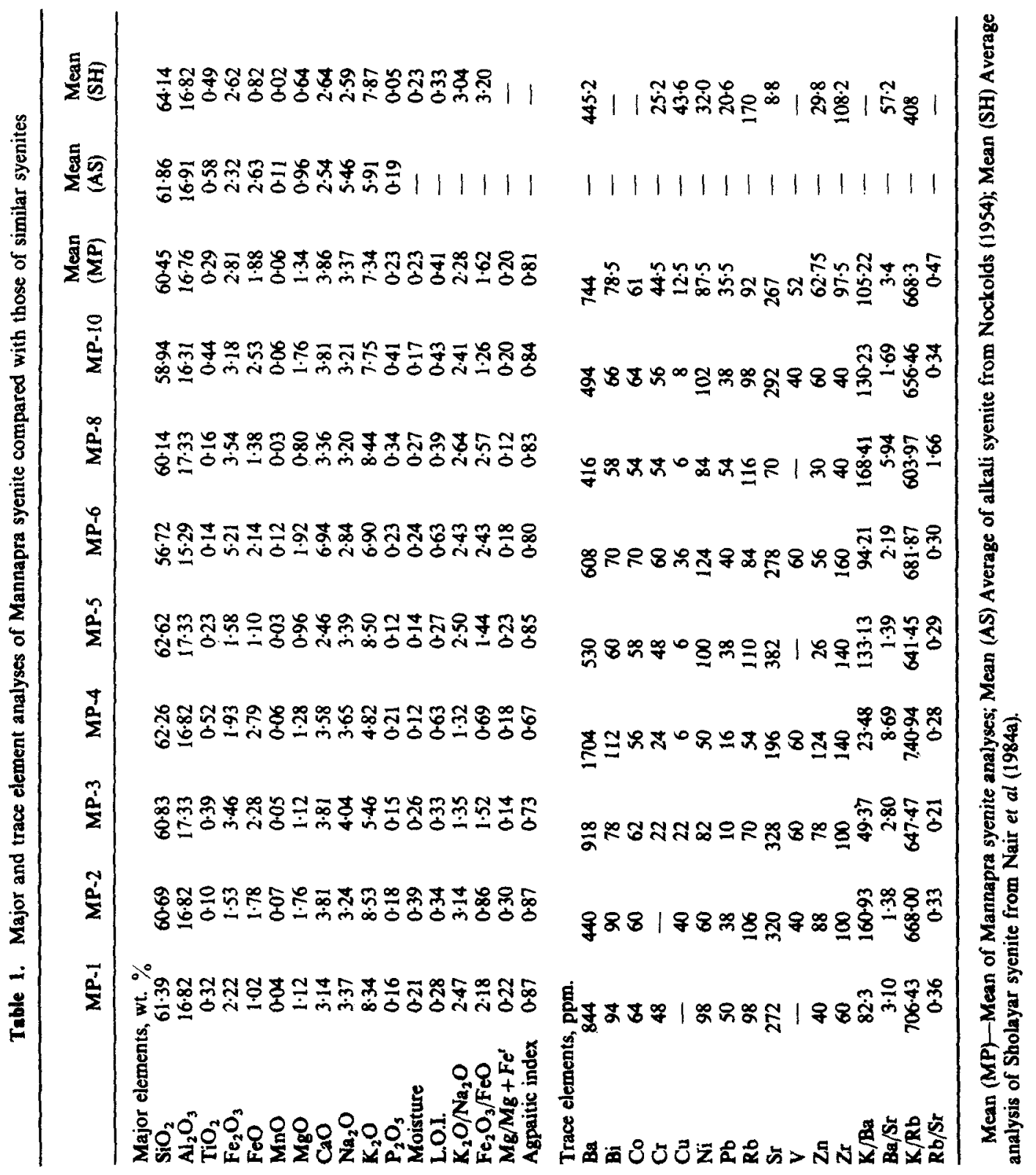


slightly higher levels of $\mathrm{CaO}$. In the absence of Ca-rich plagioclase, this component must reflect the compositional variation of the pyroxenes. The unusually higher $\mathrm{Fe}_{2} \mathrm{O}_{3}$ and $\mathrm{CaO}$ contents in one sample (MP-6) is reflected in the high modal contents of ferromagnesium minerals. $\mathrm{Na}_{2} \mathrm{O}$ (av. 3.37) and $\mathrm{K}_{2} \mathrm{O}$ (av. 7.34) are comparable with those of SH (av. 2.59 and 7.87 respectively) but differ from $\mathrm{AS}$ in having higher $\mathrm{K}_{2} \mathrm{O}$ and $\mathrm{K}_{2} \mathrm{O} / \mathrm{Na}_{2} \mathrm{O}$ ratios (av. 2.28). Higher $\mathrm{K}_{2} \mathrm{O}$ content is, however, noted to be a general feature of all alkaline plutons of the Kerala region (Nair and Santosh 1984a). $\mathrm{Na}_{2} \mathrm{O}+$ $\mathrm{K}_{2} \mathrm{O}$ (av. 10.71) is less than $\mathrm{Al}_{2} \mathrm{O}_{3}$ (av. 16.76) and in most cases is less than $1 / 6 \mathrm{SiO}_{2}$, classifying the syenite and plumasitic (Polanski 1949). With respect to total alkalies, there is a pronounced deficiency in alumina, expressed in the occurrence of up to $14.89 \%$ normative diopside (table 2). Agpaitic indices calculated for the syenite show an average of 0.81 , being close to unity. $\mathrm{Fe}_{2} \mathrm{O}_{3} / \mathrm{FeO}$ levels (av. 1.62) are slightly lower than those of $\mathrm{SH}$ (av. $3 \cdot 20$ ). $\mathrm{Mg} / \mathrm{Mg}+\mathrm{Fe}^{2}$ ratios show a variation from 0.30 to $0 \cdot 12$, consistent with a moderate degree of fractionation.

Major element variations are shown in figure 3, where they are plotted against $\mathrm{SiO}_{2}$. All the elements show overall smooth trends of variations consistent with the empirical laws governing magmatic crystallization. $\mathrm{Al}_{2} \mathrm{O}_{3}, \mathrm{~K}_{2} \mathrm{O}$ and $\mathrm{Na}_{2} \mathrm{O}$ show increasing trends with increasing $\mathrm{SiO}_{2}$. The sympathetic behaviour of these oxides is in accordance with the petrographic observation of alkali feldspar being the major liquidus phase towards the late stages of crystallization. $\mathrm{MgO}, \mathrm{FeO}^{x}$ and $\mathrm{CaO}$ show sharp decrease with increasing silica saturation, consistent with early crystallization of ferromagnesium minerals. The inter-element variations are shown in figure 4 , where $\mathrm{K}_{2} \mathrm{O} / \mathrm{K}_{2} \mathrm{O}+\mathrm{Na}_{2} \mathrm{O}$ vs $\mathrm{K}_{2} \mathrm{O}$ plots show smooth increase supporting the evidence of alkali feldspar fractionation. The $\mathrm{CaO} / \mathrm{CaO}+\mathrm{Na}_{2} \mathrm{O}$ vs $\mathrm{Al}_{2} \mathrm{O}_{3}$ plots show a sharp decline. Since plagioclase occurs only as a minor constituent, this variation records the change in pyroxene and amphibole compositions towards more sodic end members, which in turn is a reflection of the increasing peralkalinity of the liquid. Mitchell and Platt (1978) and Stephenson and Upton (1982) suggest that peralkalinity has a direct control over $\mathrm{Na}$-enrichment whereas silica saturation is rather unimportant. In this regard, the bulk rock analyses need not show peralkalinity (av. mol \% $\mathrm{Na}_{2} \mathrm{O}$ $+\mathrm{K}_{2} \mathrm{O} / \mathrm{Al}_{2} \mathrm{O}_{3}=0.81$ in the present case) as exemplified by a majority of rock suites of the Gardar Province of Greenland. $\mathrm{FeO}^{t} / \mathrm{FeO}^{t}+\mathrm{MgO}$ vs $\mathrm{Al}_{2} \mathrm{O}_{3}$ plots do not show much variation, testifying to the above view that alkalies played the determining role, as exemplified in the A-F-M and K-Na-Ca diagrams (figure 5), where the plots of the syenite closely follow an alkali enrichment trend relative to the F-M join, with a specific increase in $\mathrm{K}$ and $\mathrm{Na}$ relative to $\mathrm{Ca}$.

Among trace elements, the mean levels of Co (61 ppm), $\mathrm{Cr}$ (44.5 ppm), $\mathrm{Ni}(87.5 \mathrm{ppm})$ and $\mathrm{Zn}(62.8 \mathrm{ppm})$ are higher than those of Sholayar syenite $(30.4,25.2,32$ and $29.8 \mathrm{ppm}$ respectively). This correlates well with their entry in ferromagnesium minerals, the modal content of which is almost double $(18.2 \%)$ than that of Sholayar (av. 9.7\%). Ba (av. $744 \mathrm{ppm}$ ), Sr (av. $267 \mathrm{ppm}$ ) and $\mathrm{Zr}$ (av. $97.5 \mathrm{ppm}$ ) show higher levels where as $\mathrm{Rb}$ (av. $92 \mathrm{ppm}$ ) is rather low. The range is as follows: $\mathrm{Ba} 416-1704 \mathrm{ppm}, \mathrm{Sr}$ 70-382 ppm, Rb 54-116 ppm and $\mathrm{Zr} 40-160 \mathrm{ppm}$.

The $\mathrm{K} / \mathrm{Rb}$ ratio is high (668.3) compared to $\mathrm{SH}$ (av. 408) and that reported for syenites of the Eastern Ghat belt (333, Bose et al 1982). Ba/Sr (av. 34) and $\mathrm{Rb} / \mathrm{Sr}$ (av. $0-47$ ) values are rather low. $\mathrm{K} / \mathrm{Ba}$ shows an average of 105.2 .

Variation of trace elements with respect to $\mathrm{SiO}_{2}$ is shown in figure 6. Ba shows an overall increase which can be correlated with its partitioning in late crystallizing $\mathbf{K}$ - 
Table 2. Normative composition of Mannapra syenite

\begin{tabular}{|c|c|c|c|c|c|c|c|c|c|c|}
\hline & & MP-1 & MP-2 & MP-3 & MP-4 & MP-5 & MP-6 & MP-8 & MP-10 & Mean \\
\hline $\mathbf{Q}$ & & 3.9 & 0.66 & 7.86 & $12 \cdot 36$ & $4 \cdot 92$ & 2.04 & 2.88 & $2 \cdot 34$ & 4.62 \\
\hline or & & $49 \cdot 48$ & $50-60$ & $32 \cdot 25$ & $28 \cdot 36$ & $50 \cdot 04$ & 40.59 & 50.04 & $45-59$ & $43 \cdot 37$ \\
\hline$a b$ & & $28 \cdot 30$ & $27 \cdot 25$ & 34.06 & $30-92$ & $28 \cdot 82$ & $24 \cdot 10$ & $27 \cdot 25$ & $27-25$ & $28 \cdot 49$ \\
\hline \multirow[t]{2}{*}{ an } & & $6 \cdot 12$ & $6 \cdot 12$ & 13.07 & 15.01 & 6.95 & 8.62 & $7 \cdot 78$ & $7 \cdot 23$ & 8.86 \\
\hline & wo & 3.25 & 4.64 & 2.09 & 0.81 & 1.86 & 10.09 & 3.02 & 3.83 & $3 \cdot 70$ \\
\hline \multirow[t]{2}{*}{ di } & en & $2 \cdot 80$ & 3.00 & 1.50 & 0.40 & 1.50 & 4.80 & $2 \cdot 00$ & $2 \cdot 70$ & $2 \cdot 34$ \\
\hline & fs & - & $1 \cdot 32$ & 0.40 & 0.40 & 0.13 & - & - & 0.79 & $0-61$ \\
\hline \multirow{2}{*}{ hy } & en & - & 0.66 & 1.72 & $3 \cdot 70$ & 1.19 & - & - & $2 \cdot 24$ & 1.90 \\
\hline & fs & - & 1.40 & 0.20 & $2 \cdot 20$ & $0-10$ & - & - & $0-40$ & 0.86 \\
\hline $\mathrm{mt}$ & & $2 \cdot 32$ & $2 \cdot 32$ & $5 \cdot 10$ & 1.86 & $2 \cdot 32$ & 6.96 & 3.94 & $4 \cdot 64$ & 3.68 \\
\hline he & & 0.64 & - & - & - & - & 0.48 & $2 \cdot 72$ & - & $1 \cdot 28$ \\
\hline il & & $0-61$ & 0.15 & 0.76 & 1.06 & 0.46 & 0.30 & 0.30 & 0.91 & 0.57 \\
\hline \multirow[t]{4}{*}{ ap } & & 0.67 & $0-67$ & 0.34 & 0.34 & 0.34 & 0.67 & 0.67 & 1.01 & 0.59 \\
\hline & $\mathbf{A b}$ & $33 \cdot 73$ & $32 \cdot 45$ & $42 \cdot 91$ & 41.62 & 33.56 & 32.88 & $32-03$ & $34-03$ & $35 \cdot 40$ \\
\hline & An & $7 \cdot 29$ & $7 \cdot 28$ & $16 \cdot 46$ & 20.21 & $8 \cdot 10$ & $11 \cdot 76$ & $9 \cdot 15$ & 9.03 & $11 \cdot 16$ \\
\hline & Or & 58.98 & $60 \cdot 27$ & $40 \cdot 63$ & $38 \cdot 17$ & $58 \cdot 34$ & $55 \cdot 36$ & 58.82 & 56.94 & 53.44 \\
\hline
\end{tabular}

bearing phases. This increase in Ba with silica saturation supports the deduction that alkali feldspar constitutes the dominant fractionating phase in the syenite. Sr shows a slight increase initially, to be followed by a decrease with higher $\mathrm{SiO}_{2}$ levels, marking early precipitation of $\mathrm{Ca}$-bearing minerals, mainly apatite and pyroxene. $\mathrm{Cr}, \mathrm{Ni}$ and $\mathbf{R b}$ show scatter. However, $\mathrm{K} / \mathrm{K}+\mathrm{Na}$ vs $\mathbf{R b}$ shows a positive correlation. Interelement correlations show that $\mathrm{Ba}$ and $\mathrm{Sr}$ contents of the syenite maintain a reciprocal relationship whereas $\mathrm{Sr} v s \mathrm{Rb}$ and $\mathrm{Sr} v s \mathrm{Ca}$ plots yield overall positive correlations. $\mathrm{Zr}$ concentrates towards the residual phase.

\section{Discussion}

The absence of highly coarse mesoperthites in contrast to the Sholayar syenite and of microcline cross-hatching in the host $\mathbf{K}$-feldspar imply higher equilibration temperatures for the Mannapra syenite. The variation in the perthitic texture from fine cryptoperthite to coarser braid and patch perthites is indicative of increasing degree of fractionation aided by slow cooling rate and presence of fluids (Parsons 1978; Santosh and Nair 1985). Build-up of a fluid phase towards later stages of crystallization is best exemplified by the texture of ferromagnesium minerals. Clinopyroxenes exhibit pronounced subsolidus reaction resulting in the development of greenish pleochroic grain margins reflecting interaction between the early crystallized pyroxene and late peralkaline fluid (Mitchell and Platt 1978; Stephenson and Upton 1982). Biotite fringes around magnetite are consistent with the reaction:

$\mathrm{KAISi}_{3} \mathrm{O}_{8}$ (sanidine) $+\mathrm{Fe}_{3} \mathrm{O}_{4}$ (magnetite) $+\mathrm{H}_{2} \mathrm{O}=\mathrm{KFe}_{3} \mathrm{AlSi}_{3} \mathrm{O}_{10}(\mathrm{OH})_{22}$ (biotite) $+1 / 2 \mathrm{O}_{2}$ (Parsons 1980).

The magnetite-biotite-chlorite-amphibole assemblage also indicates subsolidus reactions (Mitchell and Platt 1982). 
The presence of plagioclase laths in orthopyroxene is significant. Such textures are reported by Philpotts (1966) and Emslie (1975), largely from pyroxenes in anorthositic rocks. Experimental data on synthetic systems and natural rock compositions demonstrate that pyroxenes with high $\mathrm{Al}_{2} \mathrm{O}_{3}$ contents are stable at high pressures and temperatures (Green and Ringwood 1967). It is recognised that aluminous pyroxenes in subalkaline and some alkaline rocks have crystallized at moderate to high pressures. The presence of exsolved Al in the form of a silica saturated phase (plagioclase) denotes that the original pyroxene did not crystallize from silica-deficient magmas. The pyroxene contained the plagieclase components in solid solution. Decompression of an initially homogeneous orthopyroxene solid solution resulted in the exsolution of a $\mathrm{NaAlSi}_{2} \mathrm{O}_{6}$-rich component (Kushiro 1969). The probability of the plagioclase laths being inclusions is not favoured since, as deduced from petrochemical features, pyroxene crystallized much earlier than plagioclase and hence the latter will not be poikilitically included in the former under normal crystallization-fractionation processes.

\section{Petrogenesis}

Based on the available petrochemical data, some inferences could be drawn regarding the petrogenesis of the syenite. Four main aspects have to be considered: (i) composition of source material, (ii) mode of melting including depth, (iii) the extent of melting and (iv) the changes in magma prior to solidification.

To start with, we assume that the source is lower crust or upper mantle. This assumption is based on the general geochemical characters of the syenite including high transition element levels and $K / \mathbf{R} b$ ratios. This assumption is substantiated by observations made on similar alkalic plutons of Kerala region (Nair and Santosh 1984a, b; Santosh and Nair 1985) as well as from the adjacent terrains (Bose et al 1982). Moreover, the syenite is emplaced along an active fault-lineament which has probable extension to mantle-depths (Nair et al 1984b) like other fault-lineaments of the region (Santosh and Sankar 1984).

In order to produce melting in the mantle, a geotherm is required to intersect the appropriate melting curve. The general processes of heating within the earth, radioactivity, thermal radiation and thermal conduction would be too diffuse to cause heat focussing (Bailey 1977). In the absence of sufficient evidences to invoke a 'mantle plume' theory, other methods of raising the temperature could be considered, namely, frictional heating or heating of the overlying rocks by a body of rising magma. The most probable mechanism of melting in stable plate interiors is mantle upwarping, producing rapid decompression melting, resulting in anorogenic magmatism. Bailey $(1974,1977)$ showed that crustal distension can cause large-scale mantle degassing leading to the addition of volatiles to the overlying rocks causing localised melting. At higher temperatures, gas fluxing can cause heat focussing which function as a doubly efficacious mechanism of melting. The intrinsic association of $\mathrm{CO}_{2}$ with metamorphic (Newton et al 1980; Harris et al 1982; Santosh 1984b) and magmatic (Nair et al 1984a; Santosh 1984a) regimes of the region is significant. We presume that the NW-SE and NNW-SSE sets of fault-lineaments of the Kerala region served as conduits for considerable volatile-influx resulting in the emplacement of a number of alkali plutons along them, including the syenite of present study. This Late Precambrian-Early 


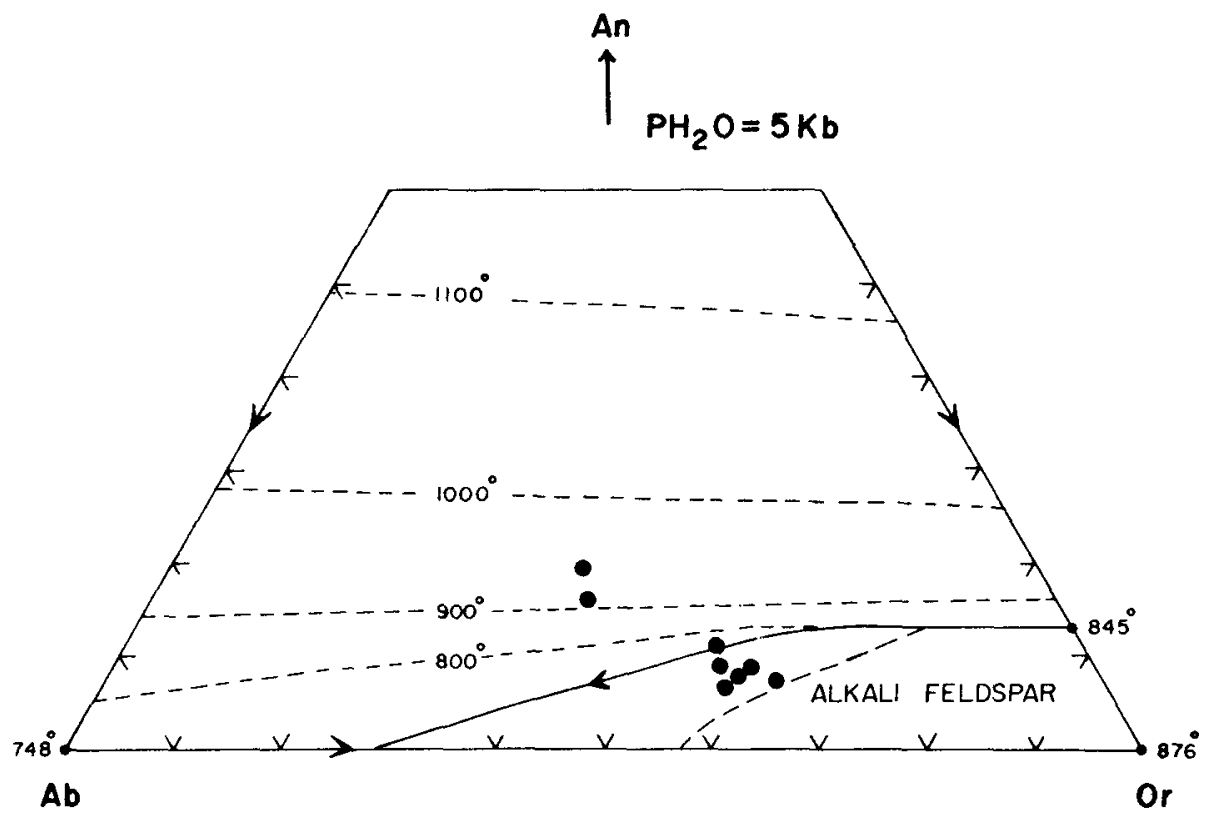

Figure 7. Part of Ab-An-Or ternary diagram with isotherms (after Yoder et al 1957) showing the plots of the Mannapra syenite.

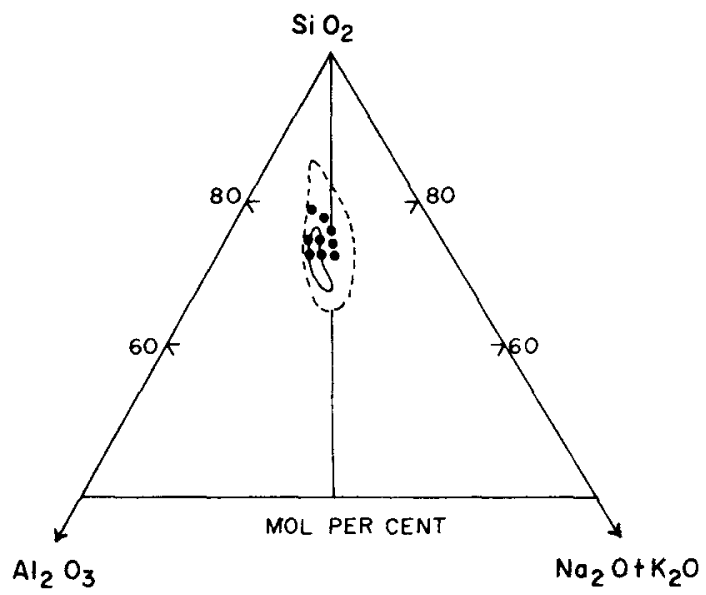

Figure 8. $\mathrm{SiO}_{2}-\mathrm{Al}_{2} \mathrm{O}_{3}-\mathrm{Na}_{2} \mathrm{O}+\mathrm{K}_{2} \mathrm{O}(\mathrm{mol} \%$ ) plots of the Mannapra syenite The broken line represents the field of syenites of the Nile Province (after Harris 1982) and the continuous line represents the field of Sholayar syenite (after Nair et al 1984b).

Paleozoic taphrogenic magmatism (Santosh and Nair 1983, 1985) serves as a keynote to the pre-rift tectonics of the Indian continental margin, as the genetic link between alkaline magmatism and rift-tectonics is well known (Bailey 1974; Murthy. and Venkataraman 1964). Anorogenic magmatism of similar age has been reported from other shield areas also (Greenberg 1981; Harris 1982).

The data presented here are insufficient to make precise estimates of the nature of source rock. However, some general deductions could be made. Melting of mica-rich 
mantle will generate potash-rich magmas whereas more sodic magmas result when amphibole-rich mantle is melted (Lloyd and Bailey 1975). Higher $\mathbf{K}$ and $\mathbf{K} / \mathbf{R b}$ levels indicate a $\mathrm{K}$-rich, but $\mathrm{Rb}$-depleted source. Low $\mathrm{Mg} / \mathrm{Mg}+\mathrm{Fe}^{t}$ levels and higher $\mathrm{Sr}$ content together with the absence of associated mafic differentiates eliminate derivation by differentiation from a basic magma and suggest partial melting. Experimental studies show that as a consequence of the incongruent melting of orthopyroxene, silica-saturated alkaline magmas can be generated from olivine-rich parent rocks (Reay and Harris 1964). The investigations of Yoder and Tilley (1962) and O'Hara (1968) indicate that at higher pressures, the mineral stabilities change, resulting in the change of position of the thermal divide in the fosterite-silica-nepheline-diopside system, leading to the formation of alkaline magmas directly by fusion and indirectly by fractionation from hypersthene-normative liquids.

Subsequent change in the magma is marked by the development of peralkalinity. Geochemical characters suggest that alkali feldspar was the dominant fractionating phase. Fractionation of feldspar ultimately leads to the development of a peralkaline residuum in any suite, especially when there is a deficiency of alumina with respect to the total alkalies (Bailey and Macdonald 1969). Feldspar being the major liquidus phase, the Ab-An-Or system has been chosen to evaluate the present data. Plots in the system (figure 7) mainly fall in the alkali feldspar solid solution field and within the bounds of $800^{\circ} \mathrm{C}$ isotherm, with a general trend towards the Or-apex. Log Sr vs log Rb plots (Condie 1973) indicate that the pressures were largely of the order of $8 \mathrm{~Kb}$. In the system relevant to peralkaline rocks, namely, the $\mathrm{SiO}_{2}-\mathrm{Al}_{2} \mathrm{O}_{3}-\mathrm{Na}_{2} \mathrm{O}+\mathrm{K}_{2} \mathrm{O}$, the plots of syenite fall within the field of similar syenites belonging to phase 2 magmatism in the Nile Province (Harris 1982) and close to the field of the Sholayar syenite (figure 8). Interestingly, the plots define a fractionation trend away from the $\mathrm{SiO}_{2}$-apex towards the region of alkalies, similar to the trend of the syenites of the Illimaussaq complex in Greenland (Macdonald 1974), consistent with the view of development of a late-stage peralkaline character, supplemented by the occurrence of up to $14.39 \%$ normative diopside. This peralkaline liquid brought about such textures as the coarsening of perthites and the subsolidus reactions of pyroxenes.

\section{Acknowledgements}

The study forms part of the CESS project (R.A.D.-4), “Acid magmatism and related metallogeny in Kerala". The authors thank the Director, Centre for Earth Science Studies, for research facilities, and Dr N G K Nair, CESS for constant encouragement.

\section{References}

Bailey D K 1974 In The alkaline rocks (ed.) H Sorensen (New York: John Wiley) p. 148

Bailey D K 1977 Igneous rocks and the degassing of earth; Tomkeieff mem. Lecture. Univ. Newcastle. 41 p.

Bailey D K and Macdonald R 1969 Am. J. Sci. 267242

Barker F and Arth J G 1976 Geology 4596

Bose M K, Ghosh-Roy A K and Czygan W 1982 Lithos 1577

Condie K C 1973 Bull. Geol. Soc. Am. 852981

Emslie R F 1975 Can. Mineral. 13138

Green D H and Ringwood A E 1967 Contr. Mineral. Petrol. 15103 
Greenberg J K 1981 Geol. Soc. Am. Bull. 92749

Harris N B W 1982 Tectonophysics 83243

Harris N B W, Holt R W and Drury S A 1982 J. Geol. 90509

Kushiro I 1969 Min. Soc. Am. Spec. Pub. 2179

Lloyd F E and Bailey D K 1975 Phys. Chem. Earth 9389

Macdonald R 1974 in The alkaline rocks (ed.) H Sorensen (New York: John Wiley) p. 442

Mahadevan T M 1964 Proc. Int. Geol. Cong. 22 Sess III 88

Mitchell R H and Platt R G 1978 J. Petrol. 19627

Mitchell R H and Platt R G 1982 J. Petrol. 23186

Murthy M V N and Venkataraman P K 1964 The Upper Mantle Symp. New Delhi p. 127

Nair N G K and Santosh M 1983 Proc. Indian Acad. Sci. (Earth Planet. Sci.) 92129

Nair N G K and Santosh M 1984a J. Geol. Soc. India 2535

Nair N G K and Santosh M 1984b Neues Jb. Miner. Abh. (in press)

Nair N G K, Santosh M and Thampi P K 1983 Neues Jb. Miner. Abh. 148223

Nair N G K, Santosh M and Thampi P K 1984a Proc. Indian Acad. Sci. (Earth Planet. Sci.) 93149

Nair N G K, Santosh M and Thampi P K 1984b Indian J. Earth Sci. 11148

Newton R C, Smith J V and Windley B 1980 Nature (London) 28845

Nockolds S R 1954 Bull. Geol. Soc. Am. 691007

O'Hara M J 1968 Earth Sci. Rev. 469

Parsons I 1978 Mineral. Mag. 421

Parsons 11980 Trans. R. Soc. Edinburgh 711

Philpotts A R 1966 J. Petrol. 71

Polanski A 1949 Bull. Soc. Amis Sci. Lett. Poznam. Serie 10119

Rao P S 1978 Geol. Surv. India Misc. Pub. 3461

Reay A and Harris P G 1964 Bull. Volcan. 27115

Santosh M 1984a Neus Jb. Miner. Mh. 6241

Santosh M 1984b Neus Jb. Miner. Mh. 8337

Santosh M and Nair N G K 1983 Proc. Indian Acad. Sci. (Earth Planet. Sci.) 92297

Santosh M and Nair N G K $1985 \mathrm{~J}$. Geol. Soc. India (in press)

Santosh M and Sankar G $1984 \mathrm{~J}$. Geol. Soc. India (under pub.)

Stephenson D and Upton B G J 1982 Mineral. Mag. 46283

Streckeisen A L 1976 Earth Sci. Rev. 121

Tilak N B G 1980 Geol. Surv. India Spec. Publ. 577

Yoder H S. Stewart D B and Smith J R 1957 Carnegie Inst. Washington Paper 1277206

Yoder H S and Tilley C E 1962 J. Petrol. 3342 